\title{
Absorption of Hemoglobin Iron: the Role of a Heme-Splitting Substance in the Intestinal Mucosa
}

\author{
Lewis R. Weintraub, Morton B. Weinstein, Hans-Jurg Huser, and \\ Sheila Rafal \\ From the Department of Hematology and the Blood Research Laboratory, \\ Tufts University School of Medicine-New England Medical Center \\ Hospitals, Boston, Massachusetts
}

\begin{abstract}
A в S TRACT The dog behaves like man in his ability to utilize dietary hemoglobin iron and, therefore, is an excellent model in which to study the mechanisms of absorption. Heme is taken up intact into the epithelial cell of the small intestine but the iron appears in the plasma in a nonheme form. A substance is present in mucosal homogenates which is capable of releasing iron from a hemoglobin substrate in vitro. This has a molecular weight greater than 64,000 , and appears to behave as an enzyme. There is no difference in the in vitro, effective concentration of the hemesplitting substance in the mucosa of iron-loaded and iron-deficient dogs to explain in vivo changes in iron absorption. However, the rate at which the heme-splitting substance works in vivo appears to be increased by the removal of the nonhemeiron-end product from the epithelial cell to the plasma. Reduction of the heme-iron content within the epithelial cell may then enhance uptake from the lumen. These studies suggest that the labile nonheme-iron content of the intestinal epithelial cell determines its ability to accept heme as well as ionized iron from the lumen.
\end{abstract}

\section{INTRODUCTION}

In this country a major source of dietary iron is found within a porphyrin ring as a constituent of hemoglobin and myoglobin. However, most of

Address requests for reprints to Dr. Lewis R. Weintraub, Tufts-New England Medical Center, 171 Harrison Avenue, Boston, Mass. 02111.

Received for publication 22 June 1967 and in revised form 13 November 1967. the investigations to date in the field of iron absorption have been performed with test doses of inorganic iron (1-3). Recently it was observed that man can absorb hemoglobin iron as efficiently as he absorbs inorganic iron, and that the addition of a nonabsorbable chelating agent reduces the absorption of inorganic iron but not hemoglobin iron (4-6). These observations suggest that iron is not released from heme in the gut lumen, but the complex is taken up intact by the intestinal epithelial cell and that, there are different pathways for the absorption of inorganic and organic iron. In an attempt to understand the handling of hemoglobin iron, studies were done in rats, mice, and guinea pigs $(7,8)$. However, these animals do not absorb hemoglobin iron efficiently, and fail to show a significant compensatory absorption in states of iron depletion as does man. Thus it is impossible to extrapolate the results of these experiments into terms of human physiology.

We have found that the dog behaves like man in his ability to absorb hemoglobin iron, and therefore, the animal is an excellent model to study hemoglobin iron absorption. The following studies were performed to delineate the mechanisms involved in the absorption of this iron complex.

\section{METHODS}

Preparation of ${ }^{59} \mathrm{Fe}$ hemoglobin. Red cells containing ${ }^{50} \mathrm{Fe}$ hemoglobin were obtained by cardiac puncture from rabbits at least 7 days after the i.v. administration of ${ }^{50} \mathrm{Fe}$ citrate. The cells were washed three times in saline and then lysed in distilled water. The stroma was removed by centrifugation at $15,000 \mathrm{~g}$ to yield a solution of hemoglobin labeled with ${ }^{50} \mathrm{Fe}$. 
In vivo absorption studies. Mongrel dogs weighing

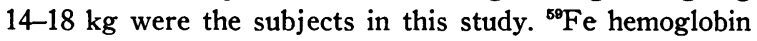
$(0.5 \mu \mathrm{c} / 0.5 \mathrm{mg}$ of $\mathrm{Fe})$ was mixed with the animal's daily portion of dog meat (total iron intake, $6-7 \mathrm{mg} /$ day) during a 3 day period. All stools were collected and the radioactivity present was counted by placing the specimens in a small animal, whole body, liquid scintillation detector (Armac, Packard Instrument Co., Inc., Downers Grove, Ill.). The collections were continued 10-14 days until there no longer was any significant radioactivity. Absorption was calculated as the difference between the total radioactivity administered and that which accumulated in the stools. A second group of dogs received a dose of hemoglobin labeled with ${ }^{50} \mathrm{Fe}(15 \mu \mathrm{c} / 5$ $\mathrm{mg}$ of $\mathrm{Fe}$ ) in a fasting state through a nasogastric tube. Periodic venous blood samples were obtained during the following $3 \mathrm{hr}$. The total radioactivity of a $5 \mathrm{ml}$ aliquot of plasma, to which a known amount of nonradioactive hemoglobin solution was added $(1.5 \mathrm{~g})$, was determined in the scintillation detector. A total of 10,000 counts were obtained on each specimen. Hemin chloride was then crystallized from this solution by the method of Labbe and Nishida (9). A weighed portion of hemin chloride was dissolved in $0.1 \mathrm{M} \mathrm{NaOH}$ and the radioactivity measured. The theoretical yield of hemin chloride was calculated from the known amount of hemoglobin in the original solution. Thus, the counts in the aliquot could be corrected to give the total number of radioactive counts in the form of heme labeled with ${ }^{50} \mathrm{Fe}$ in the original plasma sample. A control sample of ${ }^{59} \mathrm{Fe}$ bound to transferrin was added to an aliquot of hemoglobin and treated in the same manner. There was no significant radioactive contamination of the crystalized heme with ${ }^{50} \mathrm{Fe}$.

Isolation of heme labeled with ${ }^{59} \mathrm{Fe}$ from the intestinal mucosa. Normal and iron-deficient dogs in a fasting state were given a dose of hemoglobin labeled with ${ }^{59} \mathrm{Fe}$ $(15 \mu \mathrm{c} / 5 \mathrm{mg}$ of $\mathrm{Fe}$ ) through a nasogastric tube. $75 \mathrm{~min}$ later the animals were anesthetized with Nembutal and a segment of the small intestine from the gastroduodenal junction to a point $10 \mathrm{~cm}$ distal to the ligament of Treitz was removed. The intestine was opened lengthwise and washed repeatedly in cold saline (total of 6-8 liters) until there was no visible evidence of luminal contents remaining on the mucosa. The mucosa was removed by scraping the gut with a glass slide. It was then placed in a plastic bottle containing $500 \mathrm{ml}$ of saline and shaken vigorously. The bottle was centrifuged and the supernatant decanted. This procedure was repeated until less than $2 \%$ of the total radioactivity was in the wash. Nine parts of saline were then added to the mucosa and the mixture homogenized in a Virtis $45^{\prime}$ apparatus. A $10 \mathrm{ml}$ aliquot of the homogenate was added to $10 \mathrm{ml}$ of a nonradioactive solution containing $1.5 \mathrm{~g}$ of hemoglobin. The total radioactivity in this mixture was measured in the liquid scintillation detector (Armac); and hemin chloride was crystalized. The percentage of the total radioactivity in the form of heme was calculated using the procedure outlined in the previous paragraph.
In vitro determination of "heme-splitting" 1 activity in the intestinal mucosa. The small intestine was removed from fasting mongrel dogs under Nembutal anesthesia. The specimen was opened lengthwise and thoroughly washed in saline at $4^{\circ} \mathrm{C}$. The mucosa was scraped with a glass slide and mixed $1: 9$ with saline at $4^{\circ} \mathrm{C}$. This mixture was first homogenized in a glass tube with a powerdriven Teflon pestle and then a Virtis $45^{\prime}$ homogenizer. The homogenate was centrifuged at $10,000 \mathrm{~g}$ for $10 \mathrm{~min}$ and aliquots of the supernatant were used in the reaction unless otherwise state. The substrate was a solution of hemoglobin labeled with ${ }^{50} \mathrm{Fe}$ in normal human serum ( $1 \mathrm{mg}$ of $\mathrm{Hb} / \mathrm{ml}$ of serum). In most experiments $2 \mathrm{ml}$ of the hemoglobin serum solution was mixed with $5 \mathrm{ml}$ of the mucosal homogenate in a $25 \mathrm{ml}$ flask and placed in Dubnoff metabolic shaking incubator at a controlled temperature. At the end of a specific period of time the flask was placed in an ice water bath and a solution containing $1.5 \mathrm{~g}$ of nonradioactive hemoglobin was added as a carrier. Hemin chloride was crystalized. A weighed aliquot of the heme was dissolved in $0.1 \mathrm{M} \mathrm{NaOH}$ and the total radioactivity measured in the liquid scintillation detector (Armac). The radioactive $\mathrm{cpm} / \mathrm{mg}$ of heme was compared with the results obtained from a control mixture of the hemoglobin labeled with ${ }^{50} \mathrm{Fe}$ substrate solution plus saline that was treated in the same manner. Thus, the percentage of ${ }^{89} \mathrm{Fe}$ released from the hemoglobin substrate was

$$
1-\frac{\mathrm{cpm} / \mathrm{mg} \text { heme (mucosal homogenate) }}{\mathrm{cpm} / \mathrm{mg} \text { heme (saline control) }} \times 100 \text {. }
$$

Serum iron and total iron-binding capacity were determined by the method of Caraway (10). Protein concentrations were measured by either the Kjeldahl nitrogen or the Biuret method (11). Hemoglobin concentration was determined by the cyanmethemoglobin procedure (12). The following figures were used for calculations: $3.47 \mathrm{mg}$ of $\mathrm{Fe} / \mathrm{g}$ of hemoglobin; mol wt of hemin chloride, 651.9 ; mol wt of hemoglobin, 64,000 .

\section{RESULTS}

In vivo absorption studies. Four normal dogs were given $0.5 \mathrm{mg}$ of ${ }^{59} \mathrm{Fe}$ in the form of hemoglobin with their daily meal of dog meat for 3 days. The mean absorption of the test dose was $26.9 \%$ (Table I). Iron deficiency was then induced in these animals by $150-200-\mathrm{ml}$ phlebotomies every 5 days for a period of 1 month. The hemoglobin iron absorption was repeated and the mean retention of the test dose increased to $47.2 \%$. The administration of an iron-chelating substance ( $75 \mathrm{mg}$ of desferrioxamine) with the hemoglobin labeled with ${ }^{59} \mathrm{Fe}$ did not significantly

1 "Heme-splitting" will refer to the release of iron from the heme ring as measured by the disappearance of ${ }^{50} \mathrm{Fe}$ from hemin chloride crystalized from the original substrate. 
TABLE I

Hemoglobin ${ }^{59} \mathrm{Fe}$ Absorption in the Dog

\begin{tabular}{|c|c|c|c|c|}
\hline \multirow[b]{2}{*}{ Dog* } & \multicolumn{2}{|c|}{ Normal } & \multicolumn{2}{|c|}{ Postphlebotomies } \\
\hline & $\mathrm{Hb}$ & $\begin{array}{c}\mathrm{Hb}{ }^{59} \mathrm{Fe} \\
\text { absorption }\end{array}$ & $\mathrm{Hb}$ & $\begin{array}{c}\mathrm{Hb}{ }^{59} \mathrm{Fe} \\
\text { absorption }\end{array}$ \\
\hline & $\mathrm{g} / 100 \mathrm{ml}$ & $\%$ & $\mathrm{~g} / 100 \mathrm{ml}$ & $\%$ \\
\hline 1 & 15.3 & 30.9 & 8.4 & 46.8 \\
\hline 2 & 15.0 & 25.2 & 11.0 & 40.0 \\
\hline 3 & 15.8 & 25.4 & 9.1 & 66.4 \\
\hline 4 & 15.2 & 25.4 & 10.1 & 35.9 \\
\hline Mean $\pm \mathrm{SE}$ & & $26.9 \pm 1.5$ & & $47.2 \pm 6.8$ \\
\hline
\end{tabular}

* $0.5 \mathrm{mg}$ of $\mathrm{Fe}$ as $\mathrm{Hb}$ administered with daily feeding $\times 3$.

reduce the absorption of the test dose in an irondeficient animal (Table II). However, when the chelating agent was administered with a similar dose of ${ }^{59}$ ferrous sulfate there was a reduction in the absorption of iron from 56 to $1.4 \%$.

No radioactive heme was found in the plasma of four normal dogs after the administration of a dose of hemoglobin labeled with ${ }^{59} \mathrm{Fe}, 5 \mathrm{mg}$ of of $\mathrm{Fe}$, (Fig. 1). Three out of five dogs that were iron-deficient had a transient appearance of heme ${ }^{59} \mathrm{Fe}$ in the plasma. This amounted to less than $3 \%$ of the total plasma ${ }^{59} \mathrm{Fe}$ activity during the $3 \mathrm{hr}$ period of study (Fig. 2).

In vitro studies. The homogenate of the mucosa of the first segment of the small intestine when incubated with hemoglobin labeled with ${ }^{59} \mathrm{Fe}$ was able to split iron from the heme ring. The reaction was inhibited at $4^{\circ} \mathrm{C}$. Increasing the temperature of the reaction enhanced the release of of iron from hemoglobin, and a maximal activity of $56 \%$ was noted at $47^{\circ} \mathrm{C}$ for $120 \mathrm{~min}$. The rate of the reaction appeared to decrease with time (Fig. 3). Placing the homogenate in a $100^{\circ} \mathrm{C}$

TABLE II

Effect of $75 \mathrm{mg}$ of Desferrioxamine (DFO) on Iron Absorption

\begin{tabular}{ccc}
\hline Dog* & & \\
\hline 6 & $\mathrm{Hb}{ }^{59} \mathrm{Fe}$ & $\mathrm{Hb}{ }^{59} \mathrm{Fe}+\mathrm{DFO}$ \\
& $64 \%$ & $67.9 \%$ \\
7 & ${ }^{59} \mathrm{Fe} \mathrm{SO}_{4}$ & ${ }^{59} \mathrm{Fe} \mathrm{SO}_{4}+\mathrm{DFO}$ \\
& $56 \%$ & $1.4 \%$ \\
\hline
\end{tabular}

* $0.5 \mathrm{mg}$ of $\mathrm{Fe}$ as $\mathrm{Hb}$ or $\mathrm{Fe} \mathrm{SO}_{4}$ administered with daily feeding $\times 3$.

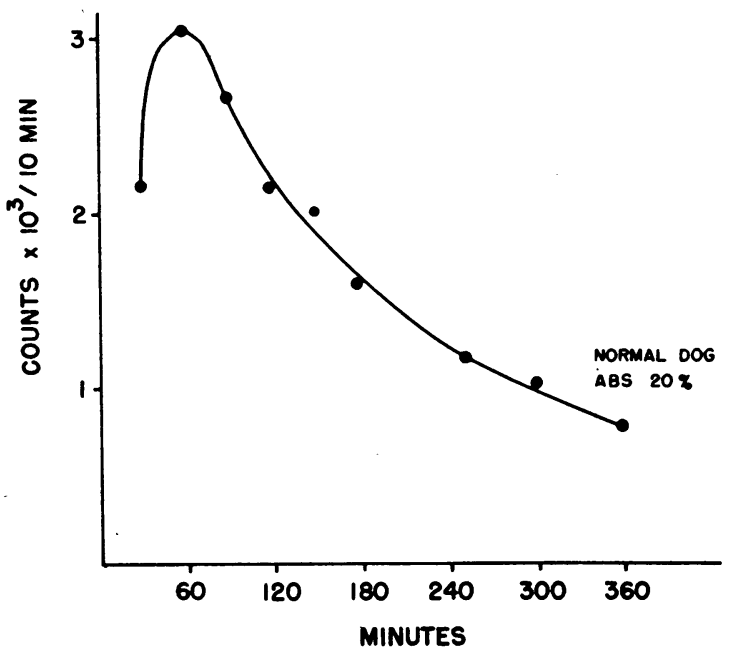

FIGURE 1 Normal dog: Plasma radioactivity after oral dose of hemoglobin labeled with ${ }^{50} \mathrm{Fe}(15 \mu \mathrm{c} / 5 \mathrm{mg}$ of $\mathrm{Fe})$. - total radioactivity.

water bath for $5 \mathrm{~min}$ before the addition of the substrate reduced the heme-splitting activity from a control value of 28.7 to $4.3 \%$ (incubation temperature/incubation time: $37^{\circ} \mathrm{C} / 60 \mathrm{~min}$ ).

The amount of iron released from a $2 \mathrm{mg}$ substrate of hemoglobin does not follow a linear relationship as the amount of intestinal homogenate added increases from 0.1 to $10 \mathrm{ml}$ (Fig. 4). Indeed, the percentage of iron released per milliliter of homogenate decreased from 35 to $3.1 \%$ per milliliter. When the amount of the substrate was increased from 0.02 to $0.1 \mathrm{mg}$ of hemoglobin there was an increase in the per cent of iron released

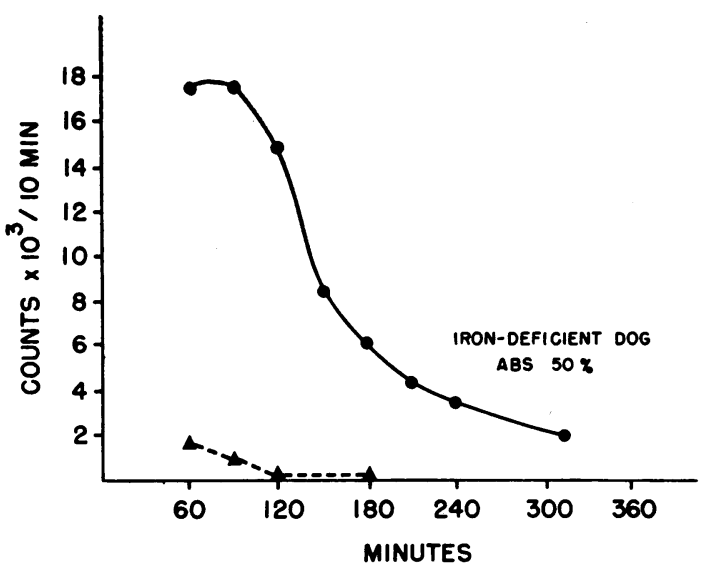

FIGURE 2 Iron deficient dog: Plasma radioactivity after oral dose of hemoglobin labeled with ${ }^{50} \mathrm{Fe}(15 \mu \mathrm{c} / 5 \mathrm{mg}$ of $\mathrm{Fe})$. - - total radioactivity. $\boldsymbol{\Delta}-\boldsymbol{\Delta}$ radioactivity as heme iron. 


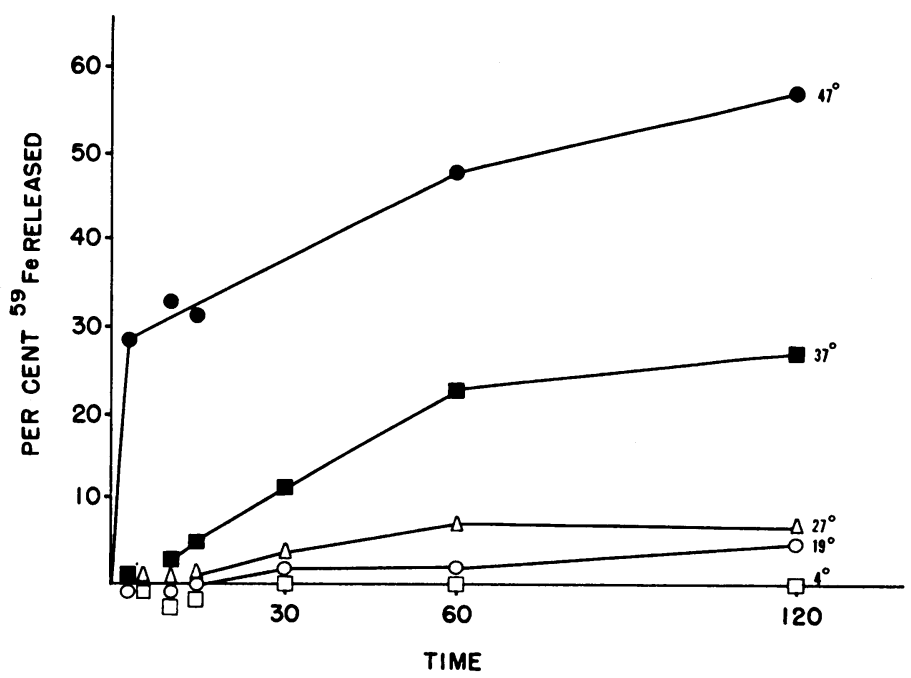

Figure 3 Effect of time and temperature on the "heme-splitting" activity of homogenate of the small intestinal mucosa. $2 \mathrm{mg}$ of $\mathrm{Hb}$ labeled with ${ }^{50} \mathrm{Fe} / 2 \mathrm{ml}$ of serum incubated with $5 \mathrm{ml}$ of mucosal homogenate. from 32.8 to $45.5 \%$ (Fig. 5). However, with further addition of substrate to $2.0 \mathrm{mg}$ of hemoglobin, the percentage of iron split fell to $32.3 \%$. This trend was reproduced in three separate experiments.

Heme-splitting activity was present in mucosal homogenates obtained from the jejunum, $21.3 \%$, and terminal ileum, $28.3 \%$ (Table III). This was in the range of the activity found in the duodenal homogenate $(26.3 \%)$ from the same animal. However, less iron was released from the substrate when stomach, $8.7 \%$, and colon, $14.7 \%$, homogenates were used. No activity was present in brain tissue. There was no correlation between the protein concentration of the homogenates and the heme-splitting activity to explain the variations noted above.

Mucosal homogenate from the duodenum was centrifuged at $50,000 \mathrm{~g}$ for $120 \mathrm{~min}$. The supernatant was then applied to a G200 Sephadex column in a refrigerated fraction-collecting apparatus. Protein concentration of the eluate was measured by the OD reading at $280 \mathrm{~m} \mu$ in a Beckman D.B. Spectrophotometer. Fractions eluted before and after a hemoglobin marker were concentrated and an aliquot from each was assayed for heme-splitting activity. The activity of the first fraction (mol wt greater than 64,000 ) was

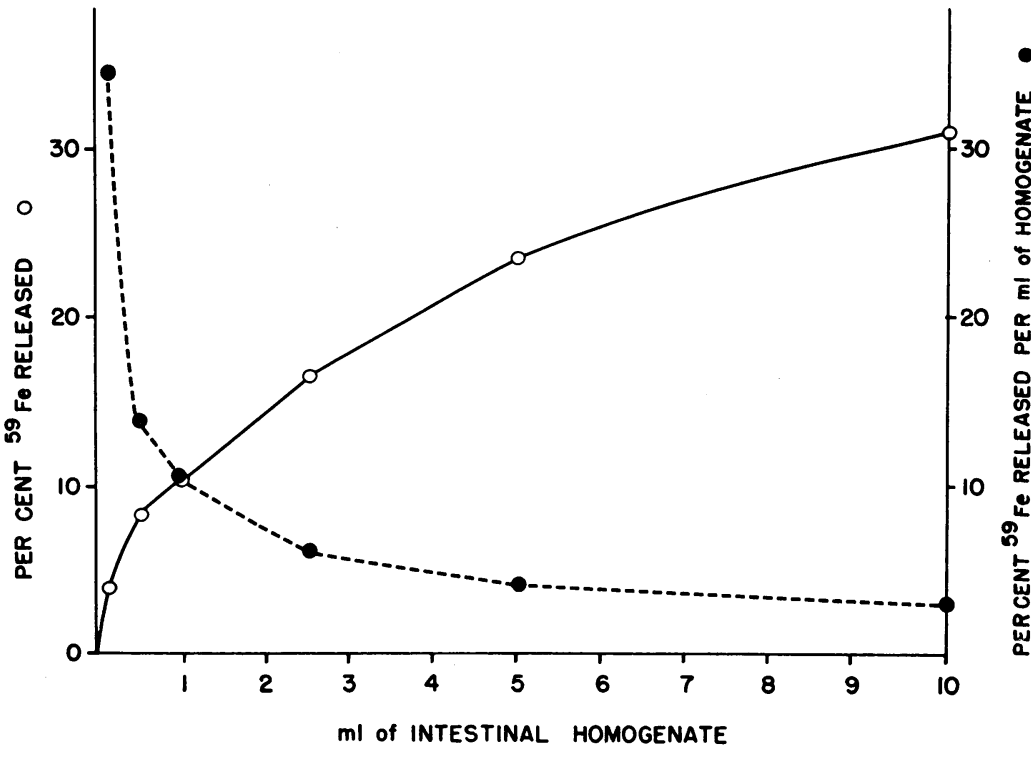

534
FIGURE 4 Effect of increasing amounts of a homogenate of intestinal mucosa on release of ${ }^{50} \mathrm{Fe}$ from a constant substrate of $2 \mathrm{mg}$ of $\mathrm{Hb}$ labeled with ${ }^{50} \mathrm{Fe} / 2 \mathrm{ml}$ of serum incubated for $60 \mathrm{~min}$ at $37^{\circ} \mathrm{C}$. 


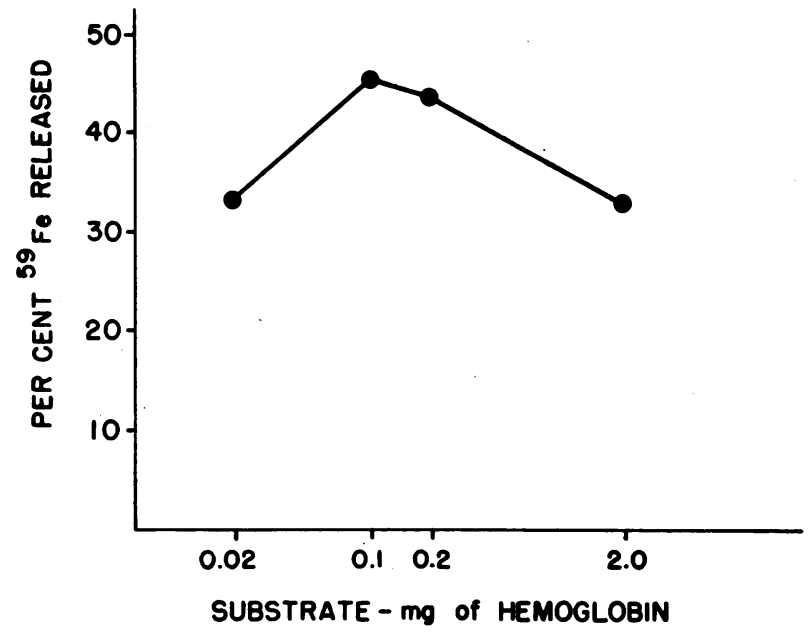

$5 \times$, but the protein concentration was only $2 / 3$ that of the second fraction (Table IV).

The percentage of iron released from $2 \mathrm{mg}$ of hemoglobin by a $5 \mathrm{ml}$ aliquot of mucosal homogenate decreases from 30.8 to $13.1 \%$ when the substrate is introduced in a saline solution $(1 \mathrm{mg}$ of $\mathrm{Hb} / \mathrm{ml}$ ) instead of human serum. There does not appear to be a significant difference between normal, iron-loaded, iron-deficient, or ahaptoglobinemic serum when used in this reaction (Table V).

The role of "heme-splitting" substance in the regulation of hemoglobin iron absorption: In vitro and in vivo studies. Homogenates were prepared from duodenal mucosa of a dog made iron-deficient by repeated phlebotomies and an iron-loaded dog who had received $10 \mathrm{~g}$ of i.m. iron-dextran (Imferon). There was no significant difference between the two in the amount of iron released from the hemoglobin substrate (Table VI).

Increasing amounts of iron in the form of ferrous sulfate were added to aliquots of normal mucosal homogenates and incubated with the hemoglobin substrate. As the iron content increased from 0 to $5 \times 10^{3} \mu \mathrm{g}$ of iron there was a
FIgURE 5 Per cent of ${ }^{50} \mathrm{Fe}$ split from varying amount of $\mathrm{Hb}$ labeled with ${ }^{50} \mathrm{Fe}$ substrates incubated for $60 \mathrm{~min}$ at $37^{\circ} \mathrm{C}$ with $5 \mathrm{ml}$ of a homogenate of intestinal mucosa. decrease in the release of iron from 45.5 to $0 \%$ (Fig. 6). However, when similar quantities of iron in the form of an iron-protein complex, ferritin, were added to the reaction there was no significant reduction in the heme-splitting activity.

Normal and iron-loaded dogs were given by nasogastric tube a standard dose of hemoglobin labeled with ${ }^{59} \mathrm{Fe}(15 \mu \mathrm{c} / 5 \mathrm{mg}$ of $\mathrm{Fe})$ in a fasting state. 75 min later the duodenum was excised and the mucosa removed. The mean percentage of the total dose of radioactivity per gram of tissue in the iron-deficient dogs, $0.018 \% / \mathrm{g}$, was lower than the normal group, $0.031 \% / \mathrm{g}$, but this is not a significant difference (Table VII). However, that fraction of the total activity in the form of nonheme iron was significantly lower in the irondeficient group, $27 \%$, than in the normals, $50.5 \%$, $(P<0.05)$.

\section{DISCUSSION}

The present study demonstrates that the dog retains a significant amount of hemoglobin iron from his diet and is capable of increasing the absorption of iron in this form when he is made iron-deficient by phlebotomies. Similar studies in

TABLE III

Heme-Splitting Activity of Various Tissues

( $2 \mathrm{mg}$ of $\mathrm{Hb}$ substrate $+5 \mathrm{ml}$ of tissue homogenate for $60 \mathrm{~min}$ at $37^{\circ} \mathrm{C}$ )

\begin{tabular}{lcccccc}
\hline & Stomach & Duodenum & Jejunum & Ileum & Colon & Brain \\
\hline & Stomach & Duodenum & Jejunum & Ileum & Colon & Brani \\
59Fe released, $\%$ & 8.7 & 26.3 & 21.3 & 28.3 & 14.7 & 0 \\
Protein concentration of homogenate, $m g / 100 m l$ & 910 & 900 & 980 & 900 & 868 & 264 \\
\hline
\end{tabular}


TABLE IV

Size Determination of Intestinal Heme-Splitting Substance

\begin{tabular}{|c|c|c|}
\hline & $\begin{array}{l}\text { Protein } \\
\text { concentra- } \\
\text { tion }\end{array}$ & $\begin{array}{l}{ }^{59} \mathrm{Fe} \text { released } \\
\text { from heme* }\end{array}$ \\
\hline Original $50,000 \mathrm{~g}$ supernatant & $\begin{array}{c}m g / 100 m l \\
780\end{array}$ & $\begin{array}{c}\% \\
32.0\end{array}$ \\
\hline $\begin{array}{l}\text { Fraction 1, G } 200 \text { Sephadex } \\
\quad(\text { mol wt }>64,000)\end{array}$ & 180 & 12.4 \\
\hline $\begin{array}{l}\text { Fraction 2, G } 200 \text { Sephadex } \\
\quad(\text { mol }<64,000)\end{array}$ & 270 & 2.4 \\
\hline
\end{tabular}

* $2 \mathrm{mg}$ of $\mathrm{Hb}$ in serum $+5 \mathrm{ml}$ of mucosal extract incubated at $37^{\circ} \mathrm{C}$ for $60 \mathrm{~min}$.

man, administering the test dose of hemoglobin with meals over a 3 day period, showed the mean absorption in normal subjects to be 23.8 compared with $49.6 \%$ in the iron-deficient state (13). These figures are equivalent to those obtained in the dog. Thus this animal, unlike rodents, behaves like man in his ability to utilize dietary hemoglobin iron. In both species, the addition of a nonabsorbable iron-chelating agent, desferrioxamine, reduces the absorption of inorganic iron but not hemoglobin iron (4-6). If the iron were released from the heme ring within the lumen of the small intestine, one would expect that it would be available for chelation and that absorption would be significantly reduced.

In the normal dog given an oral dose of hemoglobin labeled with ${ }^{59} \mathrm{Fe}, 50 \%$ of the total radio-

\begin{tabular}{cc} 
TAffect of $\begin{array}{c}\text { Serum on Heme-Splitting } \\
\text { Intestinal Homogenate }\end{array}$ & Activity of \\
\multicolumn{1}{c}{ Substrate } & $\begin{array}{c}{ }^{59 \mathrm{Fe}} \\
\text { released }\end{array}$ \\
\hline & $\%$ \\
2 mg of Hb in $2 \mathrm{ml}$ of : & $13.2^{*}$ \\
saline & $27.0^{*}$ \\
serum $(28 / 555) \ddagger$ & $30.4^{*}$ \\
serum $(77 / 384) \dagger$ & $27.8^{*}$ \\
serum $(287 / 380) \ddagger$ & $45 \S$ \\
normal serum & $42 \S$ \\
ahaptoglobinemic serum
\end{tabular}

* $5 \mathrm{ml}$ of intestinal homogenate + substrate incubated for $60 \mathrm{~min}$ at $37^{\circ} \mathrm{C}$.

$\ddagger$ Serum iron/TIBC, $\mu \mathrm{g} / 100 \mathrm{ml}$.

$\S 5 \mathrm{ml}$ of intestinal homogenate + substrate incubated for $60 \mathrm{~min}$ at $47^{\circ} \mathrm{C}$.
TABLE VI

In Vitro Heme-Splitting Activity of Mucosa from an IronDeficient and Iron-Loaded Dog

\begin{tabular}{cccc}
\hline & $\begin{array}{c}\text { Intestinal } \\
\text { homogenate } \\
\text { protein } \\
\end{array}$ & $\begin{array}{c}{ }^{59 \mathrm{Fe}} \\
\text { concentration } \\
\text { released* }\end{array}$ \\
\hline Iron-deficient & $\mu \mathrm{g} / 100 \mathrm{ml}$ & $\mathrm{mg} / 100 \mathrm{ml}$ & $\%$ \\
Iron-loaded & 54 & 920 & 47.0 \\
& 271 & 780 & 48.2 \\
\hline $2 \mathrm{mg}$ of $\mathrm{Hb} / 2 \mathrm{ml}$ of serum $+5 \mathrm{ml}$ of gut homogenate \\
incubated at $47^{\circ} \mathrm{C}$ for $60 \mathrm{~min}$.
\end{tabular}

activity in the intestinal mucosa at $75 \mathrm{~min}$ was found to be heme iron. No heme labeled with ${ }^{59} \mathrm{Fe}$ was present in the plasma. However, in three out of five iron-deficient dogs there was the transient appearance of a small amount of heme labeled with ${ }^{59} \mathrm{Fe}$ in the plasma. This was less than $3 \%$ of the total activity. Turbull, Cleton, and Finch studied the plasma of one human subject after the administration of a test dose of hemoglobin labeled with ${ }^{59} \mathrm{Fe}(4)$. No mention was made as to the status of his iron stores. They noted that less than $6 \%$ of the total radioactivity remains after ${ }^{59} \mathrm{Fe}-$ transferrin is dialyzed against an EDTA solution at $\mathrm{pH} 5.6$ where over $95 \%$ of the activity remains when a sample of hemoglobin or heme labeled with ${ }^{59} \mathrm{Fe}$ is treated in a similar manner. Plasma samples from their subject were treated in this way to determine if any heme was present. Although the authors state that no heme iron was transported to the plasma they did record in the 92,105 , and 120 min samples that, 8,7 , and $7 \%$, respectively, of the total radioactivity was present after dialysis. Thus, a small amount of heme labeled with ${ }^{59} \mathrm{FE}$ may have appeared, as in our dogs.

The intraluminal contents of the duodenum incubated in vitro with hemoglobin have been demonstrated to separate the heme ring from the globin (14). Our data suggest that the heme is then taken up intact into the epithelial cell and, subsequently, the iron is released from the heme ring and transferred to the plasma. In some instances a small amount of the heme passes directly into the plasma. In support of this concept we have demonstrated a substance in mucosal homogenates from the small intestine of dogs that is capable of releasing iron from hemoglobin in vitro. The substance is present in small concen- 


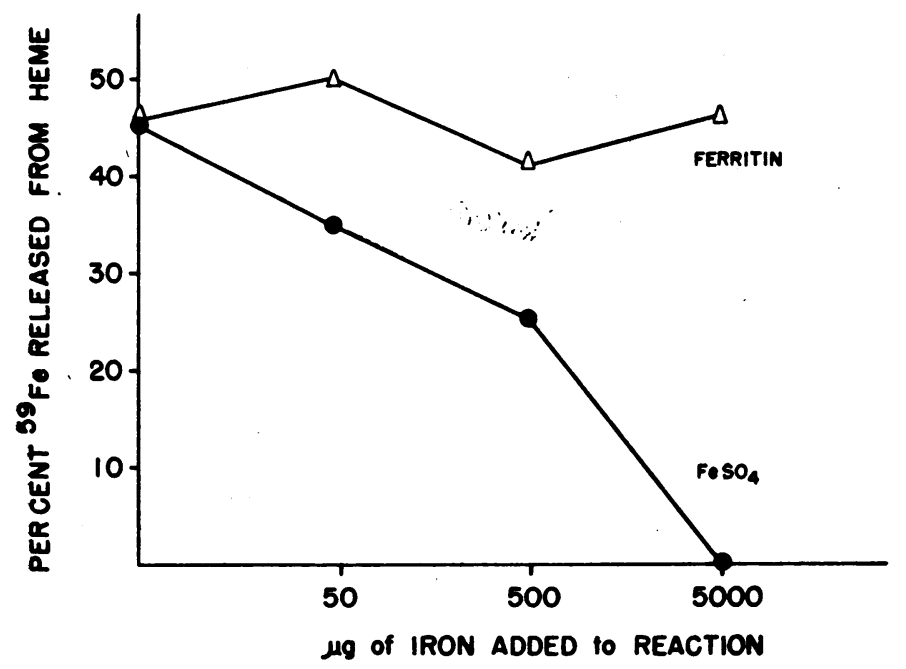

FIGURE 6 Effect of the addition of iron in the form of $\mathrm{FeSO}_{4}$ and ferritin on the per cent of ${ }^{50} \mathrm{Fe}$ released from $2 \mathrm{mg}$ of $\mathrm{Hb}$ labeled with ${ }^{50} \mathrm{Fe} /$ $2 \mathrm{ml}$ serum incubated for $60 \mathrm{~min}$ at $37^{\circ} \mathrm{C}$ with $5 \mathrm{ml}$ of a homogenate of intestinal mucosa. trations in the colon and the stomach, but not in the brain. It appears to have a mol wt greater than 64,000 and is inactivated by heating to $100^{\circ} \mathrm{C}$. That this is an enzymatic reaction is suggested by: (a) the relationship of time and temperature to the rate of the reaction, (b) partial inhibition by increasing concentration of substrate, and $(c)$ the decrease in the relative activity with increasing amounts of homogenate. Further characterization of the kinetics of this reaction awaits isolation of the heme-splitting substance. That this substance is not ascorbic acid (15) is supported by its mol wt being greater than 64,000 and its inactivity at $4^{\circ} \mathrm{C}(16)$.

Nakajima, Takemura, Nakajima, and Yamaoka found that liver and spleen homogenates from rats were able to split the porphyrin ring of hemoglobin only when the substrate was incubated with serum (17). They postulated that the hemoglobin-haptoglobin complex was necessary for the reaction to take place. Because of this observation we also incubated the hemoglobin substrate with serum and noted a significant increase in the amount of iron released. However, this potentiating effect does not appear to be related to the haptoglobin concentration, serum iron level, or transferrin saturation of the serum. Preliminary work reveals that heating the serum to $57^{\circ} \mathrm{C}$ does not alter its effect, but dialysis against a Krebs-Ringer solution reduces activity.

TABLE VII

Radioactivity in Intestinal Mucosa after Oral Dose of $\mathrm{HB}{ }^{{ }^{9} \mathrm{Fe}}$

\begin{tabular}{|c|c|c|c|c|}
\hline & $\mathrm{Hb}$ & Serum Fe & $\begin{array}{c}\text { Radioactivity in intestinal } \\
\text { epithelium }\end{array}$ & Nonheme ${ }^{59} \mathrm{Fe}$ \\
\hline \multicolumn{3}{|l|}{ Normal } & $\%$ of oral dose/g of tissue & $\%$ \\
\hline & 15.9 & 228 & 0.024 & 38.3 \\
\hline & 16.4 & 224 & 0.025 & 56.7 \\
\hline & 17.2 & 134 & 0.037 & 56.7 \\
\hline & 15.3 & 144 & 0.039 & 50.5 \\
\hline Mean $\pm \mathrm{SE}$ & & & $0.031 \pm 0.004$ & $50.5 \pm 4.3$ \\
\hline \multicolumn{5}{|l|}{ Iron-deficient } \\
\hline & 10.1 & 88 & 0.005 & 26.5 \\
\hline & 5.9 & 30 & 0.018 & 46.5 \\
\hline & 9.8 & 50 & 0.014 & 18.6 \\
\hline & 9.3 & 53 & 0.034 & 16.5 \\
\hline Mean $\pm \mathrm{SE}$ & & & $0.018 \pm 0.006$ & $27 \pm 6.9$ \\
\hline
\end{tabular}




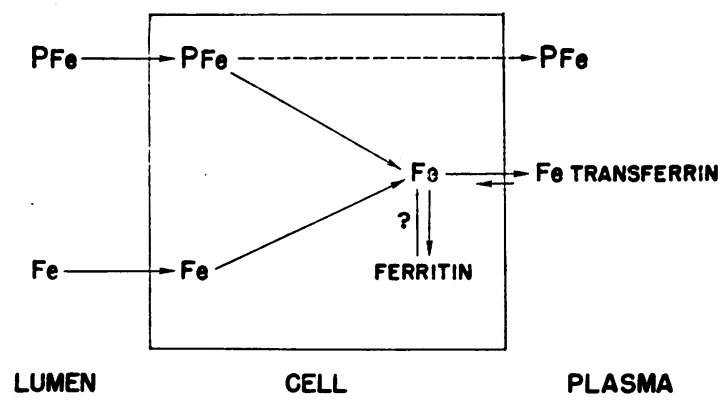

Figure 7 Proposed pathway of heme (porphyrin-bound iron, $\mathrm{PFe}$ ) and inorganic iron $(\mathrm{Fe})$ absorption in the small intestine.

There was no significant difference in the in vitro splitting of ${ }^{59} \mathrm{Fe}$ from labeled hemoglobin by the mucosal homogenate from an iron-loaded and an iron-deficient dog. Thus a change in the concentration of this substance does not appear to be responsible for the ability of the small intestine to alter the absorption of dietary hemoglobin iron as needed. The iron-deficient dog absorbs a greater quantity of iron from a test dose of hemoglobin than the normal animal; however, the amount of radioactive iron in the mucosa of the deficient $\operatorname{dog}$ is not greater than the normal dog at the time of the peak concentration in the plasma. Thus the amount of iron which crosses the intestinal mucosa per unit time must be greater in the iron-deficient state. Furthermore, the rate at which the nonheme iron leaves the cell to the plasma must be faster than the rate of uptake of heme iron from the lumen, since there is a significant decrease in the ratio of nonheme-to-heme iron in the mucosa of the iron-deficient dog. If part of the nonheme iron in the epithelial cell exists in a freely dissociable form, then a decrease of this may increase the rate of the release of iron from heme. This is analogous to the in vitro observation that, increasing the quantity of iron as ferrous sulfate but not tightly bound ferritin iron, inhibits the action of the mucosal homogenate on the hemoglobin substrate.

The present studies suggest the following hypothesis for the regulation of hemoglobin iron absorption (Fig. 7). Dietary hemoglobin iron is taken as heme into the mucosal cell and there it is acted on by a substance which appears to behave like an enzyme. The iron released may transiently exist in a freely dissociable form. That iron, which is needed by the body, is transferred to the plasma, whereas the rest is incorporated into ferritin and remains in the cell until it is sloughed from the tip of the villus $(18,19)$. In iron-deficient states there is a rapid clearance of plasma iron; this in turn depletes the nonheme-iron content of the intestinal mucosa $(20,21)$. A decrease in a freely dissociable form of nonheme iron would increase the rate at which the heme-splitting reaction takes place. Intracellular reduction of the heme iron may then enhance the further uptake of iron in this form from the lumen. A very small percentage of the heme iron may pass intact through the cell to the plasma in states of iron depletion.

Previous work in humans and rats has shown that the rate of plasma iron clearance closely regulates the labile pool of nonheme iron within the intestinal epithelial cell and that, the later level determines the ability of the cell to accept or reject dietary inorganic iron $(20,21)$. That this labile nonheme-iron pool and the subsequent transfer of iron from the cell to the plasma may be a common part of the absorption pathway of heme and inorganic iron is supported by the observation of Hallberg and Sölvell of the inhibitory effect of an oral dose of $100 \mathrm{mg}$ of ferrous sulfate iron on the absorption of $5 \mathrm{mg}$ of hemoglobin iron in man (6). Further studies are necessary to characterize the biochemical nature of the heme and nonheme iron within the epithelial cell.

\section{ACKNOWLEDGMENTS}

This work was supported by U. S. Army contract USADA-49-193-MD-2815. Dr. Lewis R. Weintraub is a recipient of U. S. Public Health Service Career award PHS-AM 31243-01. Dr. Morton B. Weinstein is a Trainee in Hematology under U. S. Public Health Service grant AM 4210-07.

\section{REFERENCES}

1. Bothwell, T. H., G. Pirzio-Biroli, and C. A. Finch. 1958. Iron absorption. I. Factors influencing absorption. J. Lab. Clin. Med. 51: 24.

2. Manis, J. G., and D. Schacter. 1962. Active transport of iron by intestine: Features of the two step mechanism. Am. J. Physiol. 203: 73.

3. Conrad, M. E., L. R. Weintraub, and W. H. Crosby. 1964. The role of the intestine in iron kinetics. J. Clin. Invest. 43: 963.

4. Turnbull, A., F. Cleton, and C. A. Finch. 1962. Iron absorption. IV. The absorption of hemoglobin iron. J. Clin. Invest. 41 : 1897. 
5. Hwang, Y. F., and E. B. Brown. 1965. Effect of desferroxamine on iron absorption. Lancet. 1: 135.

6. Hallberg, L., and L. Sölvell. 1967. Absorption of hemoglobin iron in man. Acta Med. Scand. 181: 335.

7. Weintraub, L. R., M. E. Conrad, and W. H. Crosby. 1965. Absorption of hemoglobin iron by the rat. Proc. Soc. Exptl. Biol. Med. 120: 840.

8. Conrad, M. E., L. R. Weintraub, D. A. Sears, and W. H. Crosby. 1966. Absorption of hemoglobin iron. Am. J. Physiol. 211: 1123.

9. Labbe, R. F., and G. Nishida. 1957. A new method of hemin isolation. Biochim. Biophys. Acta. 26: 437.

10. Caraway, W. T. 1963. Macro and micro methods for the determination of serum iron and iron binding capacity. Clin. Chem. 9: 188.

11. Hawk, P. B. 1965. Physiological Chemistry. B. Oser, editor. McGraw Hill Book Company, New York. 14th edition.

12. Crosby, W. H., J. I. Munn, and F. W. Furth. 1954. Standardizing a method for clinical hemoglobinometry. U. S. Armed Forces Med. J. 5: 693.

13. Kimber, C., J. F. Patterson, and L. R. Weintraub. 1967. The pathogenesis of iron deficiency anemia following partial gastrectomy: a study of iron balance. J. Am. Med. Assoc. 202: 935.

14. Conrad, M. E., S. Cortell, and L. R. Weintraub. 1966. Absorption of hemoglobin-iron: Intraluminal factors and the effect of polymerization. Clin. Res. 14: 294. (Abstr.)

15. Lemberg, R., J. W. Legge, and W. H. Lockwood. 1939. Coupled oxidation of ascorbic acid and haemoglobin. Biochem. J. 33: 754.

16. Lemberg, R., B. Cortis-Jones, and M. Norrie. 1938. Coupled oxidation of ascorbic acid and haemochromogens. Biochem. J. 32: 149.

17. Nakajima, H., T. Takemura, O. Nakajima, and $\mathrm{K}$. Yamaoka. 1963. Studies on heme alpha-methenyl oxygenase. I. The enzymatic conversion of pyridinehemichromagen and hemoglobin-haptoglobin into a possible precursor of biliverdin. J. Biol. Chem. 238: 3784.

18. Conrad, M. E., and W. H. Crosby. 1963. Intestinal mucosal mechanisms controlling iron absorption. Blood. 22 : 406.

19. Hartman, R. S., M. E. Conrad, Jr., R. E. Hartman, R. J. T. Joy, and W. H. Crosby. 1963. Ferritincontaining bodies in human small intestinal epithelium. Blood. 22 : 397.

20. Weintraub, L. R., M. E. Conrad, and W. H. Crosby. 1964. The significance of iron turnover in the control of iron absorption. Blood. 24: 19.

21. Weintraub, L. R., M. E. Conrad, and W. H. Crosby. 1965. Regulation of the intestinal absorption of iron by the rate of erythropoiesis. Brit. J. Haematol. 11: 432. 